\title{
The Effect Evaluation of Comprehensive Treatment for Groundwater Overdraft in Quzhou County, China
}

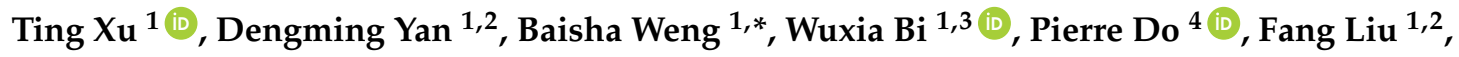 \\ Ying Wang ${ }^{1}$ and Jun Ma ${ }^{1,5}$ \\ 1 State Key Laboratory of Simulation and Regulation of Water Cycle in River Basin, China Institute of Water \\ Resources and Hydropower Research, Beijing 100038, China; xuting900515@163.com (T.X.); \\ 18519500795@163.com (D.Y.); biwuxia_1992@163.com (W.B.); 13586705638@163.com (F.L.); \\ yingwang24@126.com (Y.W.); 18303011501@163.com (J.M.) \\ 2 College of Environmental Science and Engineering, Donghua University, Shanghai 201620, China \\ 3 College of Hydrology and Water Resources, Hohai University, Nanjing 210098, China \\ 4 Institute of Water Resources and Hydrology, Department of Hydraulic Engineering, Tsinghua University, \\ Beijing 100084, China; dodmp10@mails.tsinghua.edu.cn \\ 5 School of Water Conservancy and Hydroelectric Power, Hebei University of Engineering, \\ Handan 056021, China \\ * Correspondence: baishaweng@163.com
}

Received: 12 May 2018; Accepted: 28 June 2018; Published: 30 June 2018

\begin{abstract}
In recent years, land subsidence in the plain areas of Hebei Province has caused a tremendous potential safety hazard, and has seriously hindered the social and economic development of Hebei Province. Therefore, the relevant ministries and commissions of China decided to implement comprehensive treatments to restore and protect groundwater in Hebei Province from 2014. This paper evaluates the effect of the comprehensive treatments implemented at Quzhou County in 2014 and 2015. Based on socio-economic and surface and groundwater data, the study converted "electricity to water amount" to obtain the actual amount of agricultural groundwater exploitation, and then drew the effective precipitation and agricultural groundwater exploitation amount (P-W) curve. Finally, the study calculated the restriction amount of agricultural groundwater exploitation and validated the groundwater exploitation restriction effect by the variation of groundwater depth. The restriction amounts of agricultural groundwater exploitation of the projects (including water conservancy projects, agricultural projects, and forestry projects) implemented in 2014 and 2015 were 10.54 million $\mathrm{m}^{3}$ and 5.65 million $\mathrm{m}^{3}$, respectively. The target completion ratios were $79.1 \%$ in 2014 and $100.8 \%$ in 2015 , respectively. The groundwater depths of the project regions and the county have restored to some extent. Therefore, this study illustrated that the comprehensive treatments have played an effective role in groundwater recovery and the restriction of groundwater exploitation has not caused the reduction of grain production. The results of this study can also provide effective references and technical supports of the comprehensive treatments of groundwater overdraft for other similar regions.
\end{abstract}

Keywords: groundwater overdraft; comprehensive treatment; effect evaluation; water and food security

\section{Introduction}

Groundwater is an important water resource and a major factor for maintaining the regional ecological environment, which plays a significant role in ensuring water, food, economic, and ecological security [1,2]. In the past few years, groundwater has become the main source of agricultural irrigation 
because of the wide range of distribution and convenient access [3]. The continuous extraction of groundwater every year will not only cause a decline of the local groundwater level, but also will change the local hydrological cycle and energy cycle, which will eventually affect regional climate [4-8]. At the same time, groundwater depletion will also affect the sustainability of food production, and food and water security locally and globally through the international food trade $[9,10]$. The groundwater overdraft has caused global groundwater to be exhausted at an alarming rate [11-13], especially in key food-producing regions, such as the North China Plain, the central USA and California, and north-western India $[9,10,14]$. The status mentioned above has been located and quantified by both hydrological modelling [11] and Earth observations [9,12]. As groundwater is mainly extracted by electric pumps, excessive exploitation of groundwater will increase electricity consumption, thus increasing the global carbon emissions [15]. The increase in carbon emissions not only affects global climate change, but also has a huge impact on the global economy [16]. Therefore, the problem brought about by groundwater overdraft is a global issue.

Hebei Province is the main grain-producing area of China [17]. Because of a surface water shortage, groundwater is the main source for industry and agriculture. With socio-economic development, the groundwater overdraft in Hebei Province began in the 1970s [18]. The annual average overdraft amount is up to 5.965 billion $\mathrm{m}^{3}$. The Hebei plain area became one of the areas with the highest degree of groundwater exploitation and utilization in China [19]. The long-term excessive exploitation of groundwater has caused a continuous decline in groundwater depth [19]. Combined with the influence of human activities and climate change, it has caused a series of geological and groundwater ecological environment problems, such as the deep and shallow groundwater depression cone, ground subsidence, and the migration of the salt and fresh water interface $[19,20]$. The problems of groundwater in Hebei Province have deeply affected the healthy development of regional water resources, the ecological environment and the economy, and have threatened water and food security. Therefore, it is necessary to implement the treatment of groundwater overdraft.

As the problems of the groundwater overdraft are becoming increasingly serious, a large number of domestic and foreign scholars have gradually begun to pay attention to water resources (especially environmental and ecological aspect) and other problems caused by the groundwater overdraft. Bouwer et al. and Konikow et al. found that the depletion of groundwater can eventually lead to critical environmental degradation, such as seawater intrusion and land subsidence [21,22]. Hu et al. illustrated the environmental issues caused by the groundwater overdraft, such as land subsidence, ground fissure, seawater invasion, etc. [23]. Wolff, Rothenburg et al., Holzer, and Boling have conducted research on the interaction between the groundwater overdraft and geological fractures [24-27]. Lee et al. have explored the seawater intrusion caused by groundwater overexploitation in the coastal plains of Korea [28]. Karatzas et al. insisted that in order to control the invasion of sea water, it is necessary to control the production of pumping wells and to find new alternative water sources [29]. Through the use of ground subsidence and depression data, the environmental problems caused by groundwater overexploitation were studied by Shi et al [20]. The response of climate change to the groundwater overexploitation in East Asian monsoon area and the Haihe River Basin was studied by Yuan et al. [6] and Zou et al. [30], respectively. The overdraft of groundwater also threatens food security, and some scholars have studied this issue. Yuan et al. found the food production has a close relationship with groundwater dynamics [31]. Through the study of the correlation of global food trade and groundwater depletion, Dalin et al. discovered that the current situation of the vast majority of the world's population depends on the importation of food, which highlights the risk of global food security and water safety. They also suggested that countries which both export and import food irrigated from fast exhausted groundwater were particularly exposed to these risks (including the USA, Mexico, Iran and China) [32].

As China has large food imports and exports, the threat of groundwater overdraft is more serious. The Central Committee and the State Council of China announced the Central Document No. 1 in 2014. This motion encouraged researchers to "carry out the comprehensive treatment for 
groundwater overdraft in groundwater depression cone area in North China". As Hebei is the most serious groundwater overdraft area in the world, the relevant ministries and commissions of the state organized the first annual comprehensive treatment project in Hebei Province to repair and improve the groundwater eco-environment. Some experts and scholars have explored the technology and measures to solve the problems brought about by groundwater overdraft. Sun et al. used the method of experimental comparison to probe the effect of different planting patterns on the groundwater balance in the low plain area of Hebei [17]. Chen et al. have explored and analyzed the implementation of the management measures for the comprehensive treatment of groundwater overexploitation in Hebei [33]. Li et al. found that the construction of ecological water network in Handan City is a very effective measure to restore the groundwater environment [34]. Hu's research also holds that the construction of water network in Handan plain area has an obvious supplement to shallow groundwater and improvement to groundwater environment [35]. Wang et al. analyzed the applicability of different engineering measures. They took the surface water instead of groundwater engineering in Guantao County as an example to introduce the practice and application of different water conservancy measures in groundwater overdraft control [36]. A new mode of comprehensive treatment for groundwater overdraft named as " $1+5$ " was proposed by Liu, which includes one core objective system and five innovative mechanisms [37].

However, although many scholars have done a lot of research on how to control the overdraft of groundwater, few people have explored the effectiveness of these measures. As the comprehensive treatments in Hebei have been carried out for two years, we do not know whether the treatments have been effective. Therefore, we need to evaluate the effect of comprehensive treatments for the groundwater overdraft. As Quzhou County is a region of serious shortage of water resources, the amount and degree of groundwater overdraft of the county are prominent in Hebei Province, we chose the county as the research area. On the basis of field investigation, pumping tests and data analysis in a typical area, taking the overdraft area as the key point, we evaluated the effect of different projects including water conservancy, agriculture, and forestry projects. The effect evaluation was carried out by quantitative methods to analyze the variations of groundwater exploitation amount. Then we validated the groundwater exploitation restriction effect by the variation of groundwater depth. We finally obtained the research results by combining quantitative and qualitative methods.

\section{Materials and Data}

\subsection{Study Site and Project Regions}

Quzhou County is located upstream of the Heilonggang Basin (where is the main area of groundwater overdraft in the world), in southern Hebei Province, and belongs to Handan City. The geographical scope is $114^{\circ} 50^{\prime} 30^{\prime \prime}-115^{\circ} 13^{\prime} 30^{\prime \prime} \mathrm{E}, 36^{\circ} 34^{\prime} 45^{\prime \prime}-36^{\circ} 57^{\prime} 57^{\prime \prime} \mathrm{N}$ (Figure 1). The county area is about $667.0 \mathrm{~km}^{2}$, covering five towns and five townships. The population of the county was 49,000 in $2014,90.2 \%$ of which was agricultural population. Quzhou is a typical agricultural county, especially as a core region of grain production, with variable crop types, such as wheat, corn, cotton, vegetables, etc. The cultivated land area of the county was $528.7 \mathrm{~km}^{2}$ in $2015,78.3 \%$ of which was effectively irrigated farmland. The total agricultural output value was 4.272 billion RMB in 2014, accounting for $46.5 \%$ of the county's GDP. Quzhou County is located at the middle and lower part of the alluvial plain of the ancient Yellow River and Zhang River, resulting in a very small ground slope $(1 / 30,000)$. There is just only one natural river within the territory, leading to the surface water shortage. There has always been a normal flow year or low flow year since 1991, when the surface water became scarcer. The groundwater has become the main water supply source to support the industrial, agricultural, and residential water usage, which accounted for $78.3 \%$ of the water supply in 2013. With economic and social development, the water resources in the region could not meet the needs of water usage, resulting in the groundwater overdraft. The multi-year average exploitation rate of shallow and deep groundwater were 208.1 and $124.9 \%$, respectively. The contradiction between 
supply and consumption of water resources is becoming increasingly prominent. Therefore, solving the problems of groundwater overdraft in Quzhou County is urgent.

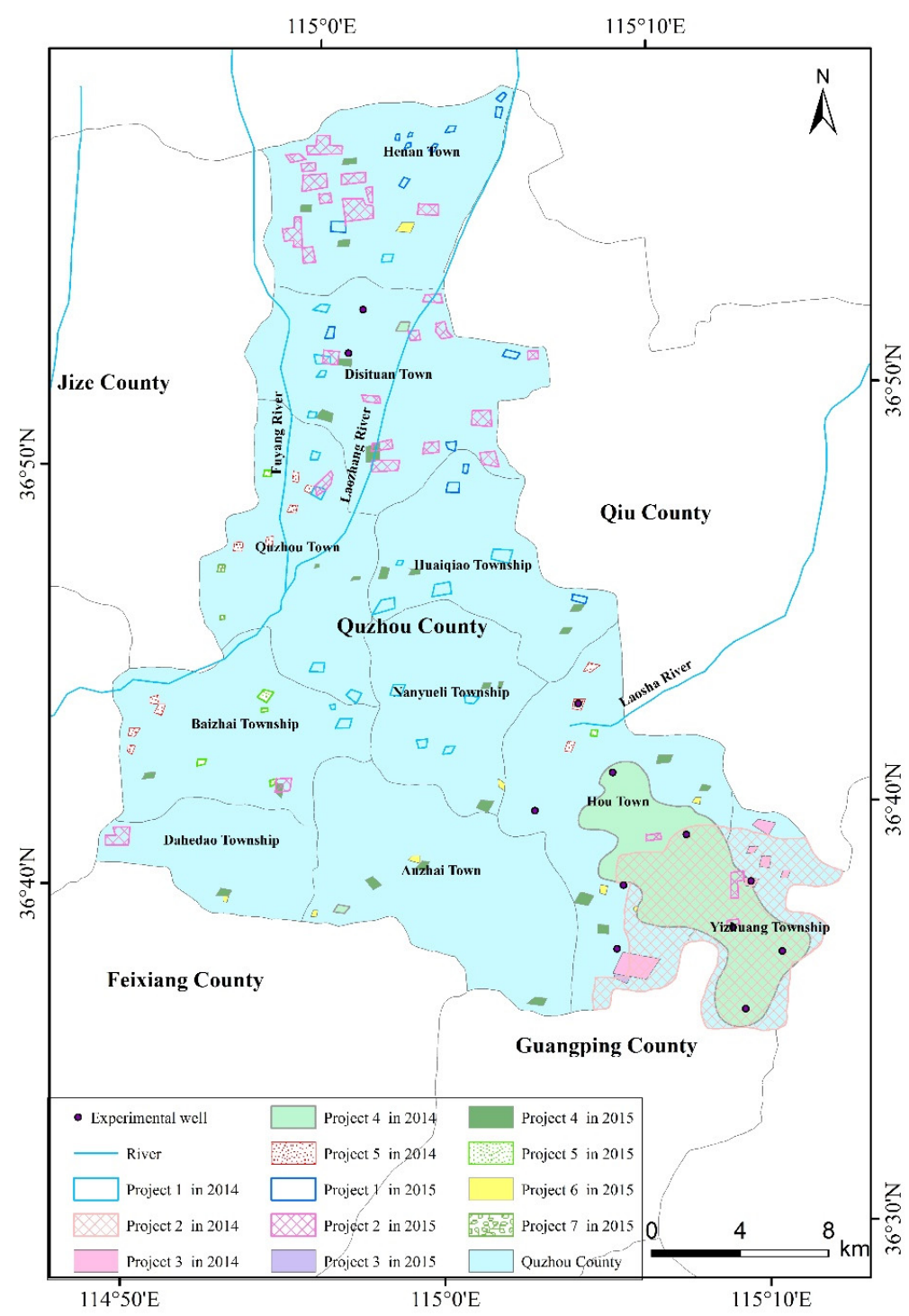

Figure 1. Distribution map of groundwater exploitation restriction projects in Quzhou.

After being identified as a pilot county for the comprehensive treatment for groundwater overdraft in 2014, Quzhou County has implemented a series of engineering measures (including water conservancy projects, agricultural projects and forestry projects) and regulation measures (including the reform of agricultural water price, the reform of the rural drinking water pipe network and the establishment of management mechanisms) to reduce groundwater exploitation in 2014 and 2015. As agricultural irrigation was the main water user, which accounted for $85.9 \%$ of the water consumption in 2013, the engineering measures were mainly implemented in agricultural areas, which we defined as project regions. In this study, we mainly evaluated the effect of the treatments implemented in project regions.

The water conservancy projects were implemented both in 2014 and 2015, including the surface water substituting groundwater projects (project 1) and the high-efficient water-saving of irrigation projects (project 2) in irrigation area (Figure 1). The project 1 covered an area of $17.1 \mathrm{~km}^{2}$ in 2014 , and $7.4 \mathrm{~km}^{2}$ in 2015 . The area of project 2 was $25.4 \mathrm{~km}^{2}$ in 2014 , and extended to a large scale with the area of $22.7 \mathrm{~km}^{2}$ in 2015 . 
The agriculture projects included the planting structure adjustment projects (project 3), the water-saving of spring irrigation for winter wheat projects (project 4), and the water and fertilizer integration of vegetable projects (project 5) in 2014 and 2015 (Figure 1). The areas of project 3, project 4, and project 5 were $6.7,24.9$, and $4.3 \mathrm{~km}^{2}$ in 2014. Project 3 was implemented in only one village (covered $0.3 \mathrm{~km}^{2}$ ) in 2015. The areas of project 4 and project 5 were 6.7 and $1.3 \mathrm{~km}^{2}$ in 2015 . The county has implemented new water and fertilizer integration of wheat-corn projects (project 6) in 2015, with an area of $1.3 \mathrm{~km}^{2}$.

The county has also implemented forestry projects (project 7) in 2015. The planting area was $0.7 \mathrm{~km}^{2}$, located at Quzhou Town and Yizhuang Township (Figure 1).

\subsection{Data Sources}

The data used in this study includes basic information of Quzhou County (including geographic data, area data, etc.), social and economic development data (including population, economic data, etc.), agricultural data (including planting structure, agricultural electricity consumption data, etc.), water resources data (including water resources amount, water supply and consumption data, groundwater depth information, etc.), meteorological data (including the precipitation from 1956 to 2016), treatment project materials, forestry data, and other information of Quzhou County. The specific information about the data are shown in Table 1.

Table 1. Data sources.

\begin{tabular}{lll}
\hline Data & Source & Description \\
\hline $\begin{array}{l}\text { Basic information, social and economic development data. } \\
\text { Water resources amount, water supply and consumption }\end{array}$ & Statistical Yearbook of Quzhou County & from 2011 to 2016 \\
data, and water conservancy project materials. & Water Conservancy Bureau of Quzhou County & from 2011 to 2016 \\
Groundwater depth data. & Hydrological Bureau of Handan City & from 2008 to 2016 \\
Meteorological data. & Hydrological Bureau of Hebei Province & from 1956 to 2016 \\
Planting structure data and agricultural project materials. & Agriculture and Animal Husbandry Bureau of & Quzhou County 2013 to 2016 \\
Forestry data. & Forestry Bureau of Quzhou County & 2016 \\
Agricultural irrigation electricity consumption data. & Electric Power Bureau of Quzhou County. & from 2005 to 2016 \\
Electricity consumption and pumping volume. & Pumping tests & 2015 and 2016 \\
\hline
\end{tabular}

\section{Methods}

Based on the project investigation, the experimental observation of groundwater exploitation and groundwater depth, the study compared the groundwater exploitation amount and groundwater depth before and after the comprehensive treatments, and also combined the quantitative and qualitative methods to evaluate the effect of groundwater withdrawal restrictions. Since the implementation of the restriction measures promoted in 2014, we identified 2013 as the pre-treatment baseline year. Considering that most of the treatment projects implemented in 2014 and 2015 were not completed until the end of the year, the effect evaluation of the projects should be carried out in subsequent years, and we identified 2015 and 2016 as the post-treatment baseline years for the treatment projects implemented in 2014 and 2015, respectively. Therefore, in 2015, we evaluated the effect of the projects implemented in 2014, and in 2016, we evaluated the effect of the new projects implemented in 2015. The research methods are as follows:

\subsection{Overview of the Study}

The overview of the study is illustrated by the following procedures. Considering all factors, we chose Quzhou County as the research area. After investigating all the basic information in Quzhou County, the implementation of treatment projects was carried out in the overdraft regions, which called project regions. Now, the main work of this study is to assess whether these projects have played a positive role in relieving and restoring the groundwater overdraft in the study area. The purpose of the evaluation is that, if the results of the evaluation are effective, we will affirm the treatment projects and 
analyze the results of the evaluation; if the results are not effective, we will make suggestions to adjust the treatment projects. The evaluation process are shown as the Figure 2, including data analysis, calculation of groundwater exploitation in pre-treatment baseline year, calculation of groundwater exploitation in post-treatment baseline years, evaluation of groundwater exploitation restriction in post-treatment baseline years, and verification of the groundwater exploitation restriction effect by groundwater depth variation. The effect evaluation is completed by 13 steps as shown in Figure 2.

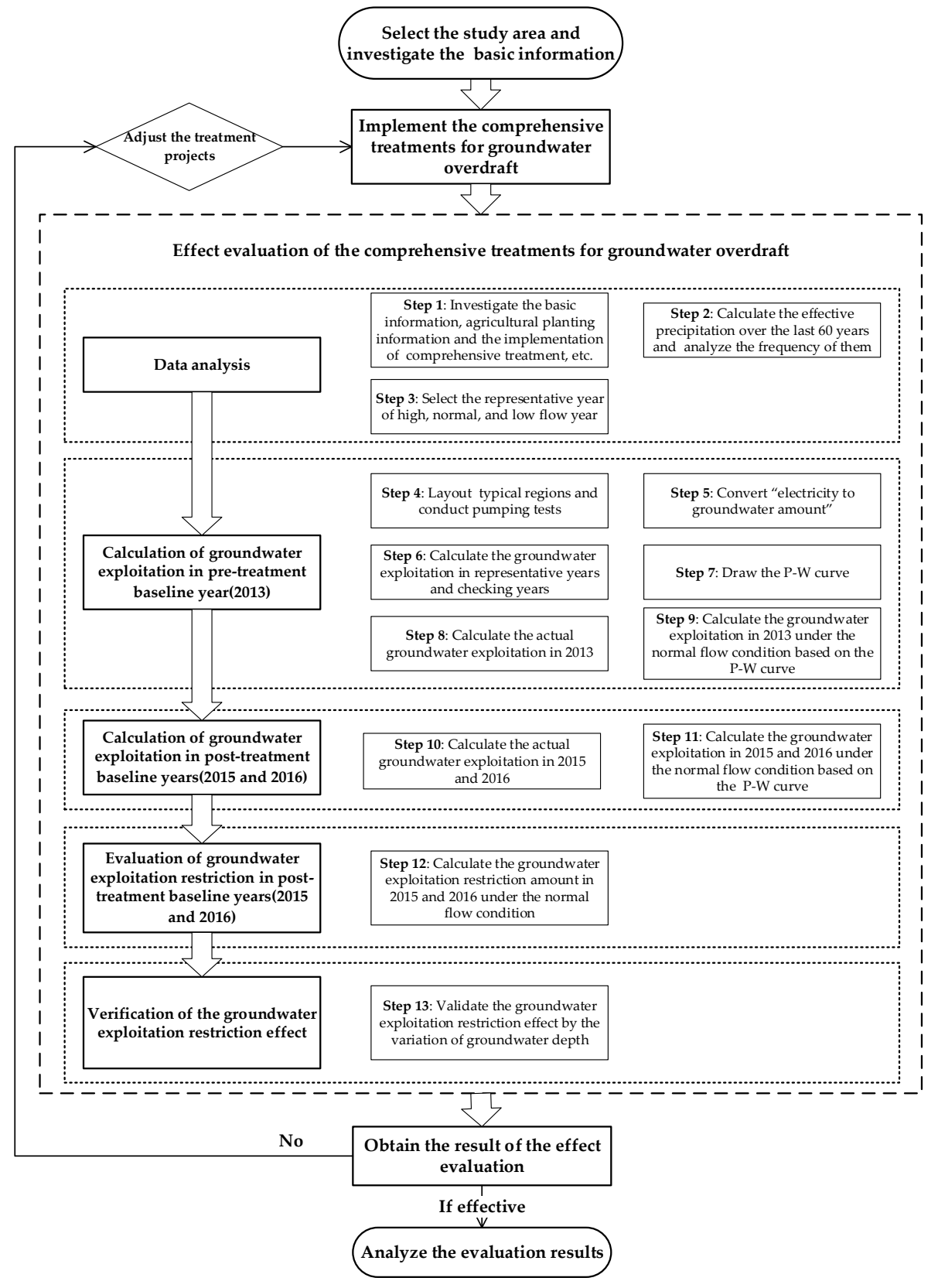

Figure 2. The overview of the study.

\subsection{Layout of Typical Regions and Conduct of Pumping Tests}

Most of the agricultural area in Quzhou County is irrigated by groundwater from wells. There are a large number of wells, supervised by individual farmers or collective organizations, scattered in the whole county. Most of the wells have not installed volume measurement facilities. However, due to the payment of electricity in the irrigation wells, the electricity consumption in the wells was 
generally recorded. It is the only valuable practical measurement data that can be used to calculate the groundwater exploitation amount, when combined with groundwater exploitation amount per kilowatt hour (which is called the "converting electricity to water amount"). We have selected wells both in project regions and non-project regions to conduct pumping tests and obtain the data of exploitation amount per kilowatt hour to calculate groundwater exploitation amount. According to the spatial superposition analysis of the distribution of the projects, the wells, the transformers, the soil lithology, and the crops, six typical regions were identified through the screening, which were distributed in a project 1 region, a project 2 region, a project 3 region, a project 4 region, a project 5 region, and a non-project region, respectively. Two wells in each project region and three wells in the non-project region were selected (Figure 1).

The groundwater exploitation amount per kilowatt hour in a single well is an important parameter to calculate groundwater exploitation amount. The electricity consumption was obtained by a pumping test in each observation well, and the pumping capacity was measured by a portable flow meter in the field (Figure 3). From the tests, we obtained the groundwater exploitation amount per kilowatt hour in an individual well in the project 1 region, project 2 region, project 3 region, project 4 region, and project 5 region, which were $2.17,1.76,1.43,1.28$, and $1.66 \mathrm{~m}^{3}$, respectively (Table 2); the groundwater exploitation amount per kilowatt hour in an individual well in the non-project regions of wheat, corn, and cotton were $1.81,1.68$, and $1.52 \mathrm{~m}^{3}$, respectively (Table 3).

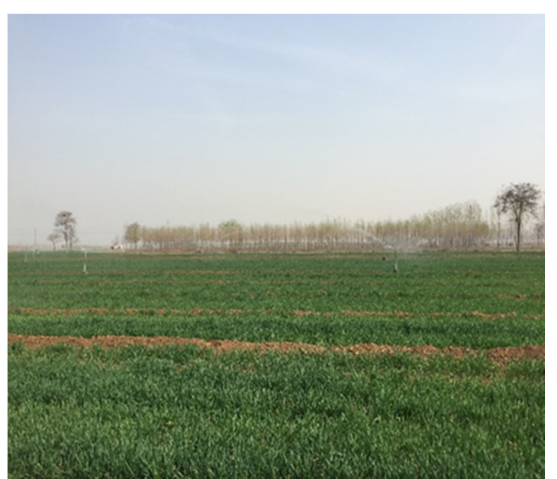

(a)

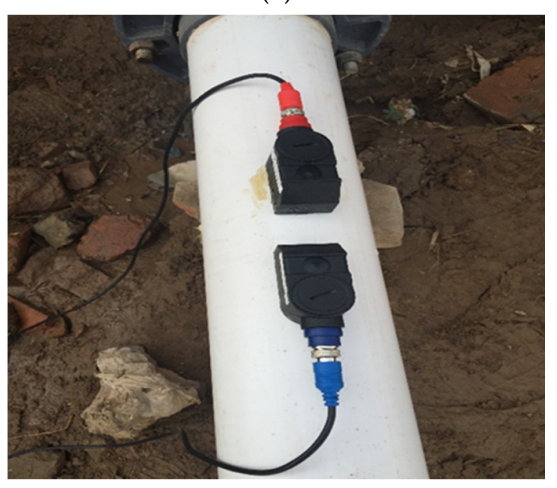

(c)

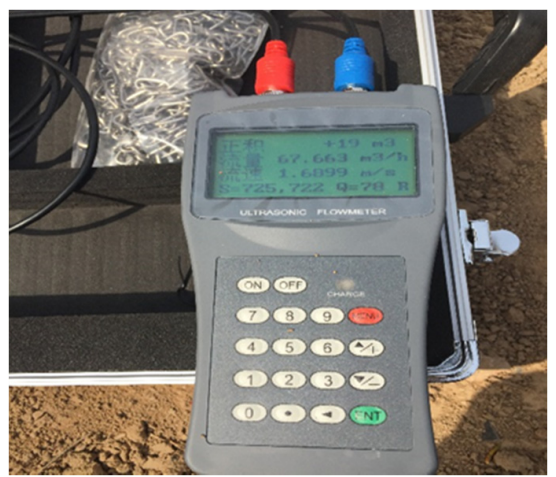

(b)

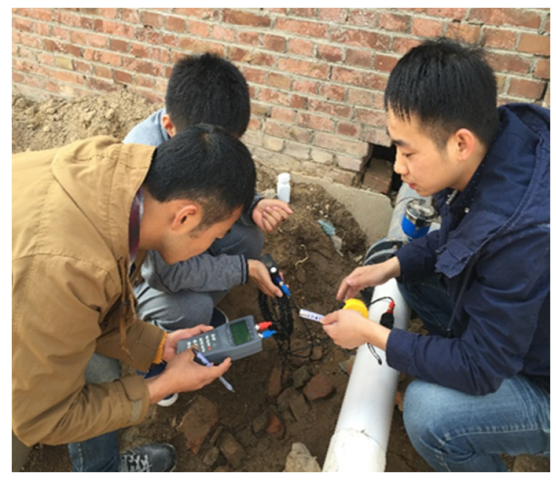

(d)

Figure 3. Pumping test in the field. (a) Wheat field in project region; (b) Handheld Ultrasonic Flow Meter (Flowmeter, HT-003UF, Beijing, China); (c) The sensor of Handheld Ultrasonic Flow Meter (Flowmeter, HT-003UF, Beijing, China); and (d) Experimental field. The photos were taken by Dr. Xu Ting in the project region in Houcun, Quzhou County on 30 March 2016; there are no copyright issues for these pictures. 
Table 2. Results of pumping test in typical area of project regions.

\begin{tabular}{|c|c|c|c|c|c|c|c|}
\hline \multirow{2}{*}{$\begin{array}{l}\text { Project } \\
\text { Number }\end{array}$} & \multirow[t]{2}{*}{ Plant Type } & \multirow{2}{*}{$\begin{array}{l}\text { Groundwater } \\
\text { Pumping } \\
\text { Amount }\left(\mathrm{m}^{3}\right)\end{array}$} & \multirow{2}{*}{$\begin{array}{c}\text { Electricity } \\
\text { Consumption } \\
(\mathrm{Kw} \cdot \mathrm{h})\end{array}$} & \multirow{2}{*}{$\begin{array}{c}\text { Groundwater } \\
\text { Exploitation Amount } \\
\left(\mathrm{m}^{3} / \mathrm{Kw} \cdot \mathrm{h}\right)\end{array}$} & \multicolumn{3}{|c|}{$\begin{array}{c}\text { Groundwater Consumption } \\
\text { Amount }\left(10^{4} \mathrm{~m}^{3} / \mathrm{km}^{2}\right)\end{array}$} \\
\hline & & & & & High & Normal & Low \\
\hline 1 & Wheat, corn & 13.2 & 6.07 & 2.17 & 26.9 & 37.9 & 40.6 \\
\hline 2 & Wheat, corn & 26.9 & 15.3 & 1.76 & 30.9 & 34.5 & 39.0 \\
\hline 3 & Wheat, corn & 25.0 & 17.5 & 1.43 & 32.9 & 38.8 & 49.0 \\
\hline 4 & Wheat & 17.0 & 13.4 & 1.28 & 28.2 & 34.2 & 44.8 \\
\hline 5 & Vegetables & 26.7 & 16.1 & 1.66 & 42.0 & 47.6 & 54.4 \\
\hline
\end{tabular}

Groundwater pumping amount means the groundwater pumping amount during the pumping test period; electricity consumption means the electricity consumption during the pumping test period; groundwater exploitation amount means groundwater exploitation amount per kilowatt hour; the High, Normal, and Low mean the representative years of high, normal, and low flow, respectively; the project numbers are the same as mentioned above.

Table 3. Results of pumping test in typical area of non-project regions.

\begin{tabular}{|c|c|c|c|c|c|c|}
\hline \multirow{2}{*}{$\begin{array}{l}\text { Plant } \\
\text { Type }\end{array}$} & \multirow{2}{*}{$\begin{array}{l}\text { Groundwater } \\
\text { Pumping } \\
\text { Amount }\left(\mathrm{m}^{3}\right)\end{array}$} & \multirow{2}{*}{$\begin{array}{l}\text { Electricity } \\
\text { Consumption } \\
(\mathrm{Kw} \cdot \mathrm{h})\end{array}$} & \multirow{2}{*}{$\begin{array}{c}\text { Groundwater } \\
\text { Exploitation Amount } \\
\left(\mathrm{m}^{3} / \mathrm{Kw} \cdot \mathrm{h}\right)\end{array}$} & \multicolumn{3}{|c|}{$\begin{array}{l}\text { Groundwater Consumption } \\
\text { Amount }\left(10^{4} \mathrm{~m}^{3} / \mathrm{km}^{2}\right)\end{array}$} \\
\hline & & & & High & Normal & Low \\
\hline Wheat & 15.57 & 8.6 & 1.81 & 26.3 & 33.9 & 40.8 \\
\hline Corn & 14.9 & 8.9 & 1.68 & 19.5 & 23.5 & 32.6 \\
\hline Cotton & 11.86 & 7.8 & 1.52 & 15.6 & 17.2 & 21.4 \\
\hline
\end{tabular}

The meanings of the head phrases are as mentioned above.

\subsection{Determination of the Representative Years of High, Normal, and Low Flow}

We determined the representative years of high, normal, and low flow by frequency distribution of effective precipitation. Effective precipitation refers to the amount of precipitation needed to meet crop evapotranspiration during crop growth period. Because precipitation can be stagnant in soil, the larger precipitation per day may be effectively utilized by crops in the next few days, so effective precipitation has statistical characteristics of time periods. Through fitting tests, we found that the fitting curve of effective precipitation in 10 days and agricultural groundwater exploitation in the county has the optimal structure and highest fitting degree, so the effective precipitation was counted by the 10-day scale. Effective precipitation is closely related to crop water requirement, and the study counted effective precipitation by calculating crop water requirements. The daily crop water requirement was calculated by the crop coefficient method, and the calculation formulas are as follows:

$$
P_{e c}=\sum_{i=1}^{n} P_{t e i} \quad\left\{\begin{array}{c}
P_{t e}=W_{t c}, \quad P_{t}>W_{t c} \\
P_{t e}=P_{t}, \quad P_{t} \leq W_{t c}
\end{array} \quad W_{t c}=\sum_{i=1}^{10} W_{d c i} \quad W_{d c}=K_{c} \times E T_{c}\right.
$$

where $P_{e c}$ is effective precipitation during crop growth period of a certain crop, $\mathrm{mm}$; $P_{t e i}$ is the effective precipitation in 10 days, $\mathrm{mm} /(10$ day $) ; P_{t e}$ is the effective precipitation in 10 days, $\mathrm{mm} /(10$ day $) ; P_{t}$ is the precipitation in 10 days, $\mathrm{mm} /\left(10\right.$ day); $W_{t c}$ is crop water requirement in 10 days, $\mathrm{mm} /(10 \mathrm{day})$; $W_{d c}$ is daily crop water requirement, $\mathrm{mm} /$ day; $E T_{c}$ is reference crop evapotranspiration, calculated by the Penman-Monteith formula, $\mathrm{mm} /$ day; and $K_{c}$ is the crop coefficient, determined by the method of piecewise single value average crop coefficient.

Based on the planting structure of the county and the effective precipitation during crop growth period of a certain crop, which were calculated by Equation (1), we calculated the yearly effective precipitation of the county by Equation (2):

$$
P_{e}=\sum_{i=1}^{n}\left(P_{e c i} \times A_{i}\right) / \sum_{i=1}^{n} A_{i}
$$


where $P_{e}$ is effective precipitation in a year of the county, $\mathrm{mm} /$ year; $P_{e c i}$ is effective precipitation during crop growth period of crop $i, \mathrm{~mm} /$ year; $A_{i}$ is the irrigated area of crop $i, \mathrm{~km}^{2}$, and it is necessary to note that the area of irrigation could not be repeated when calculating the effective precipitation of the county; in this case, the replanting area of the crop needs to be calculated separately.

According to the temporal variations of precipitation and effective precipitation from 1956 to 2016 in Quzhou County, the inter-annual precipitation showed a significant fluctuation, and it presented a gradual decline trend with a decline rate of $18.7 \mathrm{~mm} /(10$ year) on the whole (Figure 4$)$. Effective precipitation also presented the same change trend with a decline rate of $14.6 \mathrm{~mm} /(10$ year). The multi-year average precipitation and effective precipitation were 474.5 and $321.1 \mathrm{~mm}$, respectively. The minimum precipitation and effective precipitation were 187.5 and $115.7 \mathrm{~mm}$, respectively, which occurred in 1992, while the maximum precipitation and effective precipitation were 1069.6 and $763.6 \mathrm{~mm}$, which were 5.7 and 6.6 times the minimum value, respectively, which happened in 1973. From the above results, the annual precipitation was distributed unevenly.

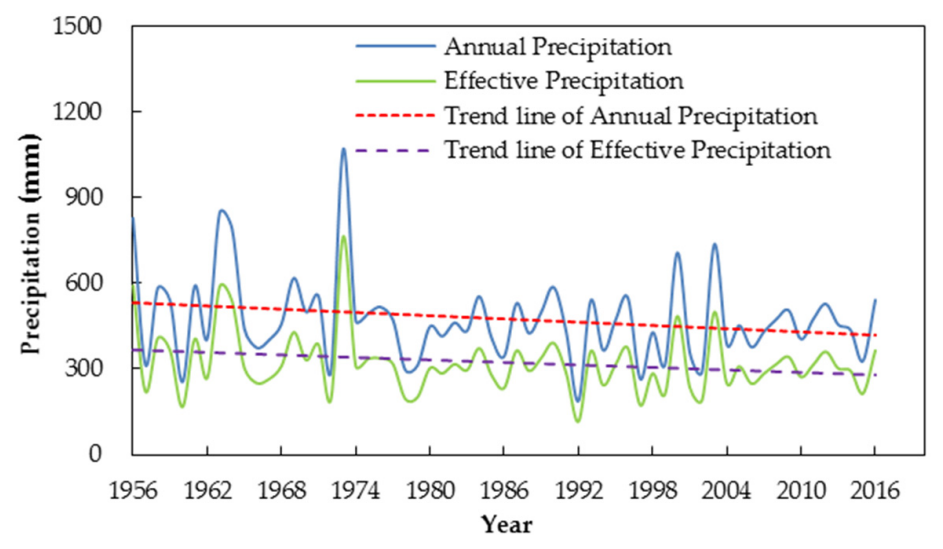

Figure 4. The temporal variations of precipitation from 1956 to 2016 in Quzhou County.

In order to determine the high, normal, and low representative years, we ranked the effective precipitation from 1956 to 2013 (the precipitation series before the treatments) and applied the Pearson III curve to fit and check the series (the fitting degree was 0.95). According to the fitted curve, the reference effective precipitations with frequency of 25,50 , and $75 \%$ were $363.7,308.5$, and $249.5 \mathrm{~mm}$, respectively, which were recorded as $P_{25}, P_{50}$, and $P_{75}$, respectively. Based on the $P_{25}, P_{50}$, and $P_{75}$, we selected the high, normal, and low representative years within a recent 10 years (from 2004 to 2013), which were 2012, 2005, and 2006, respectively. The effective precipitation of the representative years were $360.0,308.5$, and $248.2 \mathrm{~mm}$, respectively, which were recorded as $P_{e-h}, P_{e-n o r}$, and $P_{e-l}$, respectively.

\subsection{Calculation of Groundwater Exploitation in the Representative Years of High, Normal, and Low Flow}

Based on the results of the irrigation regions investigation and the agricultural planting structure analysis, the data obtained by pumping tests, and the agricultural irrigation electricity consumption data, we calculated the groundwater exploitation in the high, normal and low flow representative years. If there were $N$ groundwater irrigation regions in the county, and there were $S$ crop types in each irrigation region in 2013, the calculation formulas are as follows:

$$
W_{h}=\sum_{i=1}^{N} \sum_{j=1}^{S}\left(w_{i, j}^{h} \times a_{i, j}^{2013}\right), W_{n o r}=\sum_{i=1}^{N} \sum_{j=1}^{S}\left(w_{i, j}^{n o r} \times a_{i, j}^{2013}\right), \quad W_{l}=\sum_{i=1}^{N} \sum_{j=1}^{S}\left(w_{i, j}^{l} \times a_{i, j}^{2013}\right)
$$

where $a_{i, j}^{2013}$ is the irrigation area of crop $j$ in irrigation region $i$ in the pre-treatment baseline year (2013), $\mathrm{km}^{2} ; w_{i, j}^{h}, w_{i, j}^{n o r}$, and $w_{i, j}^{l}$ are the groundwater exploitation amount per square kilometer of crop $j$ in irrigation region $i$ in high, normal, and low flow representative years (2012,2005, and 2006), respectively, based on the crop structure in $2013, \mathrm{~m}^{3} / \mathrm{km}^{2}$, which were calculated by the agricultural 
irrigation electricity consumption data in high, normal, and low flow representative years and the pumping test data, listed in the Tables 2 and 3 ; and $W_{h}, W_{n o r}$, and $W_{l}$ are the agricultural groundwater exploitation amount of the county in high, normal, and low flow representative years, respectively, $\mathrm{m}^{3}$.

\subsection{P-W Curve Drawing}

The P-W curve means the relationship curve of the effective precipitation and agricultural groundwater exploitation amount. Effective precipitation is related to crop water requirement and inter-annual precipitation distribution. For specific crops, there are differences in the amount of precipitation used by crops under the same annual precipitation and different annual precipitation distribution. Crop water requirements, which have not been satisfied by effective precipitation, need to be supplemented by agricultural irrigation. As groundwater is the main source of irrigation water in this county, there is a correlation between effective precipitation and agricultural groundwater exploitation. The greater the ratio of effective precipitation to crop water demand, the smaller amount of agricultural groundwater exploitation are needed, and vice versa. By drawing the P-W curve, we can understand the change relationship between agricultural groundwater exploitation and effective precipitation more thoroughly. Based on the data we have obtained, we used the effective precipitation and agricultural groundwater exploitation amount in the representative years of high (2012), normal (2005), and low (2006) flow $\left(\left(P_{e-h}, W_{h}\right),\left(P_{e-n o r}, W_{n o r}\right),\left(P_{e-l}, W_{l}\right)\right)$ of the county to get a power curve in the $X-Y$ coordinate system. Then, we chose two other years (2008 and 2013) in the recent 10 years to validate and calibrate the curve. After using the corresponding data to check the power curve, we finally obtained the optimal P-W curve (with determination coefficient $R^{2}=0.9098$ ) (Figure 5).

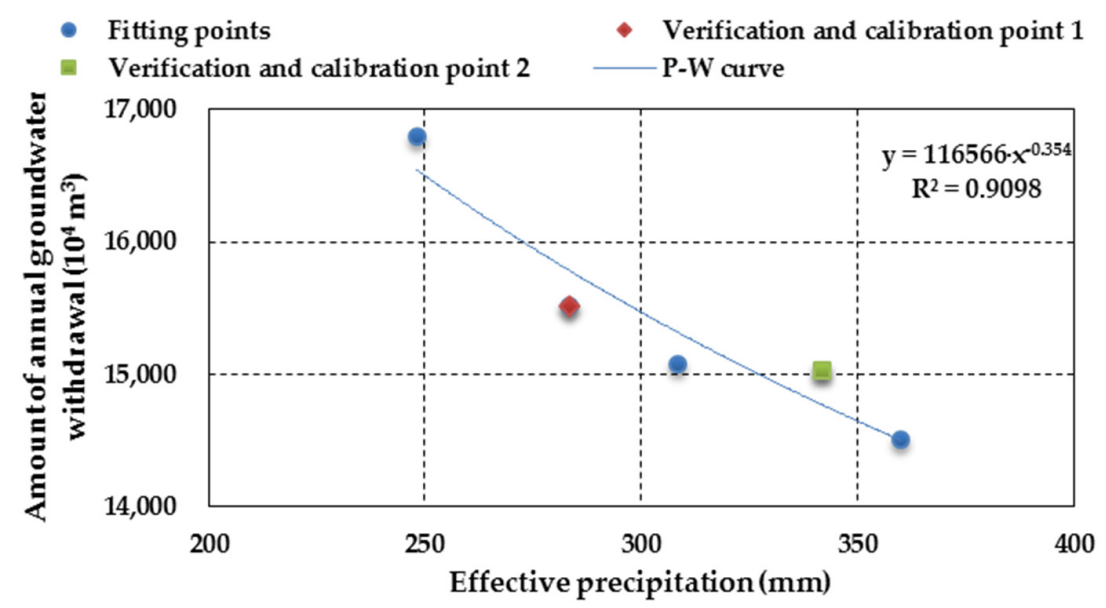

Figure 5. The effective precipitation and agricultural groundwater exploitation amount (P-W) curve of Quzhou County.

\subsection{Calculation of Groundwater Exploitation Restriction Amount}

Because the frequency and the annual distribution of the precipitation in the pre-treatment baseline year (2013) and post-treatment baseline years (2015 and 2016) were inconsistent, it was obviously lacking a comparison basis and was thus less scientific to calculate the groundwater exploitation restriction by the difference of the actual agricultural groundwater exploitation in the pre-treatment baseline year and post-treatment baseline years. If the pre-treatment baseline year is a low flow year, while the post-treatment baseline years are high flow years, there is no need to implement any measures, and the agricultural groundwater utilization may be reduced. Conversely, the groundwater exploitation may even increase after the implementation of restriction measures. Therefore, we converted the actual agricultural groundwater exploitation of the pre-treatment baseline 
year and post-treatment baseline years to the condition of a normal flow year, then evaluated the agricultural groundwater exploitation restriction.

The actual amounts of agricultural groundwater exploitation in the post-treatment baseline years were calculated by Equation (4):

$$
W_{2015 / 2016}^{a c t}=\sum_{i=1}^{N} \sum_{j=1}^{S}\left(w_{i, j}^{2015 / 2016} \times a_{i, j}^{2015 / 2016}\right)
$$

where $W_{2015 / 2016}^{a c t}$ is the actual amount of groundwater exploitation in 2015 or $2016, \mathrm{~m}^{3} ; w_{i, j}^{h 2015 / 2016}$ is the groundwater exploitation per square kilometer of crop $j$ in irrigation region $i$ in 2015 or 2016, $\mathrm{m}^{3} / \mathrm{km}^{2} ; a_{i, j}^{2015 / 2016}$ is the irrigation area of crop $j$ in the irrigation region $i$ in 2015 or 2016, $\mathrm{km}^{2}$; and $N$ and $S$ are the same as mentioned above.

The agricultural groundwater exploitation under the normal flow condition in the post-treatment baseline years were obtained by a conversion coefficient. The conversion principle is that the ratios of the groundwater exploitation in different years and the groundwater exploitation under normal flow conditions in a region are relatively stable. The conversion equations are as follows:

$$
W_{2015 / 2016}^{\text {nor }} / W_{2015 / 2016}^{a c t}=W_{2013}^{\text {nor }} / W_{2013}^{P W, 2015 / 2016}, W_{2015 / 2016}^{\text {nor }}=\frac{W_{2013}^{\text {nor }}}{W_{2013}^{P W, 2015 / 2016}} \times W_{2015 / 2016}^{a c t}
$$

where $W_{2015 / 2016}^{n o r}$ is the groundwater exploitation amount under the normal flow condition in 2015 or 2016, $\mathrm{m}^{3} ; W_{2013}^{\text {nor }}$ is the groundwater exploitation amount under the normal flow condition in 2013, $\mathrm{m}^{3}$, which was obtained from the P-W curve corresponding to the precipitation of the frequency of $50 \%\left(P_{50}\right)$; and $W_{2013}^{P W, 2015 / 2016}$ is the groundwater exploitation amount obtained from the P-W curve corresponding to the effective precipitation in 2015 or 2016, $\mathrm{m}^{3}$.

Based on the comparison of the agricultural groundwater exploitation amount under the condition of normal flow in pre-treatment baseline year and post-treatment baseline years, we calculated the restriction amount of agricultural groundwater exploitation in 2015 and 2016 by Equation (6):

$$
W_{2015 / 2016}^{\text {res }}=W_{2013}^{\text {nor }}-W_{2015 / 2016}^{\text {nor }}
$$

where $W_{2015 / 2016}^{r e s}$ is the restriction amount of agricultural groundwater exploitation in 2015 or 2016, $\mathrm{m}^{3}$; and the other symbols are the same as those described above.

\section{Results and Discussion}

\subsection{Actual Amount of Agricultural Groundwater Exploitation Before and After Treatments}

Based on the pumping tests and crop planting structure survey, we obtained the irrigation water consumption per square kilometer in the six typical regions (Table 4). The water consumption of vegetables and wheat rank the first and second, respectively, indicating that it is possible to reduce the groundwater consumption by shrinking the planting area of vegetables and wheat appropriately. It is worth noting that the water consumption in the forest area was also high, the possible reason for which was that the water consumption of the tree was larger in the first year of being planted. According to the data collected from six typical regions and project regions, we calculated the actual amount of agricultural groundwater exploitation before and after treatments in different project regions. The total actual amount of agricultural groundwater exploitation in 2015 and 2016 were 30.07 million $\mathrm{m}^{3}$ and 10.74 million $\mathrm{m}^{3}$, respectively, of which the exploitation amount of water conservancy projects and agricultural projects were 16.04 million $\mathrm{m}^{3}$ and 14.03 million $\mathrm{m}^{3}$ in $2015,7.82$ million $\mathrm{m}^{3}$ and 2.62 million $\mathrm{m}^{3}$ in 2016, respectively; the exploitation amount of forestry projects was 0.31 million $\mathrm{m}^{3}$ in 2016. The total actual amount of agricultural groundwater exploitation in 2013 of the regions 
corresponding to the project regions implemented in 2014 and 2015 were 35.37 million $\mathrm{m}^{3}$ and 14.26 million $\mathrm{m}^{3}$, respectively.

Table 4. Actual amount of agricultural groundwater exploitation in the project regions of Quzhou County.

\begin{tabular}{|c|c|c|c|c|c|c|c|}
\hline Year & $\begin{array}{c}\text { Treatment } \\
\text { Project }\end{array}$ & $\begin{array}{l}\text { Project } \\
\text { Number }\end{array}$ & $\begin{array}{c}\text { Area } \\
\left(\mathrm{km}^{2}\right)\end{array}$ & $\begin{array}{c}\text { Water } \\
\text { Consumption } \\
\left(10^{4} \mathrm{~m}^{3} / \mathrm{km}^{2}\right)\end{array}$ & $\begin{array}{c}\text { Actual } \\
\text { Amount } 1 \\
\left(10^{4} \mathrm{~m}^{3}\right)\end{array}$ & $\begin{array}{c}\text { Actual } \\
\text { Amount } 2 \\
\left(10^{4} \mathrm{~m}^{3}\right)\end{array}$ & $\begin{array}{c}\text { Actual } \\
\text { Restriction } \\
\text { Amount } \\
\left(10^{4} \mathrm{~m}^{3} / \mathrm{km}^{2}\right)\end{array}$ \\
\hline \multirow{8}{*}{2015} & \multirow{2}{*}{$\begin{array}{c}\text { Water } \\
\text { conservancy } \\
\text { projects }\end{array}$} & 1 & 17.1 & 35.1 & 600.9 & 725.2 & 7.3 \\
\hline & & 2 & 25.4 & 39.5 & 1003.2 & 1288.5 & 11.2 \\
\hline & \multicolumn{2}{|c|}{ Subtotal } & 42.5 & & 1604.1 & 2013.7 & 9.6 \\
\hline & \multirow{3}{*}{$\begin{array}{l}\text { Agricultural } \\
\text { projects }\end{array}$} & 3 & 6.7 & 38.0 & 254.7 & 358.1 & 15.4 \\
\hline & & 4 & 24.9 & 37.3 & 929.4 & 893.0 & -1.5 \\
\hline & & 5 & 4.3 & 50.9 & 218.8 & 271.7 & 12.3 \\
\hline & \multicolumn{2}{|c|}{ Subtotal } & 35.9 & & 1402.9 & 1522.8 & 3.3 \\
\hline & \multicolumn{2}{|c|}{ Total } & 78.4 & & 3007.0 & 3536.5 & 6.8 \\
\hline \multirow{10}{*}{2016} & \multirow{2}{*}{$\begin{array}{c}\text { Water } \\
\text { conservancy } \\
\text { projects }\end{array}$} & 1 & 7.4 & 18.8 & 139.0 & 205.8 & 9.0 \\
\hline & & 2 & 22.7 & 28.3 & 643.0 & 847.9 & 9.0 \\
\hline & \multicolumn{2}{|c|}{ Subtotal } & 30.1 & & 782.0 & 1053.7 & 9.0 \\
\hline & \multirow{4}{*}{$\begin{array}{l}\text { Agricultural } \\
\text { projects }\end{array}$} & 3 & 0.3 & 25.0 & 7.5 & 10.5 & 10.0 \\
\hline & & 4 & 6.7 & 23.8 & 159.3 & 219.3 & 9.0 \\
\hline & & 5 & 1.3 & 47.1 & 61.2 & 65.3 & 3.2 \\
\hline & & 6 & 1.3 & 25.8 & 33.5 & 45.5 & 9.2 \\
\hline & \multicolumn{2}{|c|}{ Subtotal } & 9.6 & & 261.5 & 340.6 & 8.2 \\
\hline & $\begin{array}{l}\text { Forestry } \\
\text { projects }\end{array}$ & 7 & 0.7 & 43.9 & 30.7 & 32.0 & 1.9 \\
\hline & \multicolumn{2}{|c|}{ Total } & 40.5 & & 1074.2 & 1426.3 & 8.7 \\
\hline
\end{tabular}

Actual amount 1 means the actual amount of agricultural groundwater exploitation in post-treatment baseline years (2015/2016); Actual amount 2 represents the actual amount of agricultural groundwater exploitation in pre-treatment baseline year (2013) corresponding to the project regions implemented in 2014 or 2015; the project numbers are the same as above.

The total restriction amount per square kilometer in 2015 and 2016 were $6.8 \mathrm{~m}^{3}$ and $8.7 \mathrm{~m}^{3}$, respectively, indicating that the restriction effect in 2016 was better. However, the effective precipitation in $2015(214.2 \mathrm{~mm})$ was less than the $P_{75}(249.5 \mathrm{~mm})$. It was a low flow year, in which year groundwater consumption maybe increased significantly due to the lack of precipitation, in spite of the restriction measures implemented. While the effective precipitation in 2016 was $364.4 \mathrm{~mm}$, it was a high flow year $\left(P_{25}=363.7 \mathrm{~mm}\right)$, in which year there is no need to implement any measures, and the agricultural groundwater utilization may be reduced. Considering the erroneous judgment brought by neglecting the influence of precipitation on actual exploitation in different years, we converted the actual agricultural groundwater exploitation in 2013, 2015 and 2016 to the conditions of the normal flow year to evaluate the restriction amount of agricultural groundwater exploitation.

\subsection{Groundwater Exploitation Restriction Amount Under the Normal Flow Condition}

After converting the exploitation amount of agricultural groundwater in the pre-treatment year and post-treatment years to the amount under the normal flow conditions, we obtained the result of the restriction measurements effect. The total restriction amount of agricultural groundwater exploitation under normal flow conditions in 2015 was 10.54 million $\mathrm{m}^{3}$ (with the exploitation amount of 20.67 million $\mathrm{m}^{3}$ in 2015 and 31.21 million $\mathrm{m}^{3}$ in 2013), of which the restriction amounts of water 
conservancy projects and agricultural projects were 6.74 million $\mathrm{m}^{3}\left(11.03\right.$ million $\mathrm{m}^{3}$ in 2015 and 17.77 million $\mathrm{m}^{3}$ in 2013) and 3.80 million $\mathrm{m}^{3}$ (9.64 million $\mathrm{m}^{3}$ in 2015 and 13.44 million $\mathrm{m}^{3}$ in 2013), respectively (Figure 6a). The total exploitation amount of agricultural groundwater exploitation under normal flow condition in 2016 was 5.65 million $\mathrm{m}^{3}$ (11.98 million $\mathrm{m}^{3}$ in 2016 and 17.63 million $\mathrm{m}^{3}$ in 2013), of which the restriction amount of water conservancy projects, agricultural projects and forestry projects were 4.08 million $\mathrm{m}^{3}$ (8.96 million $\mathrm{m}^{3}$ in 2016 and 13.04 million $\mathrm{m}^{3}$ in 2013), 1.39 million $\mathrm{m}^{3}$ (2.92 million $\mathrm{m}^{3}$ in 2016 and 4.31 million $\mathrm{m}^{3}$ in 2013 ), and 0.18 million $\mathrm{m}^{3}\left(0.1\right.$ million $\mathrm{m}^{3}$ in 2016 and 0.28 million $\mathrm{m}^{3}$ in 2013 ), respectively (Figure 6b).

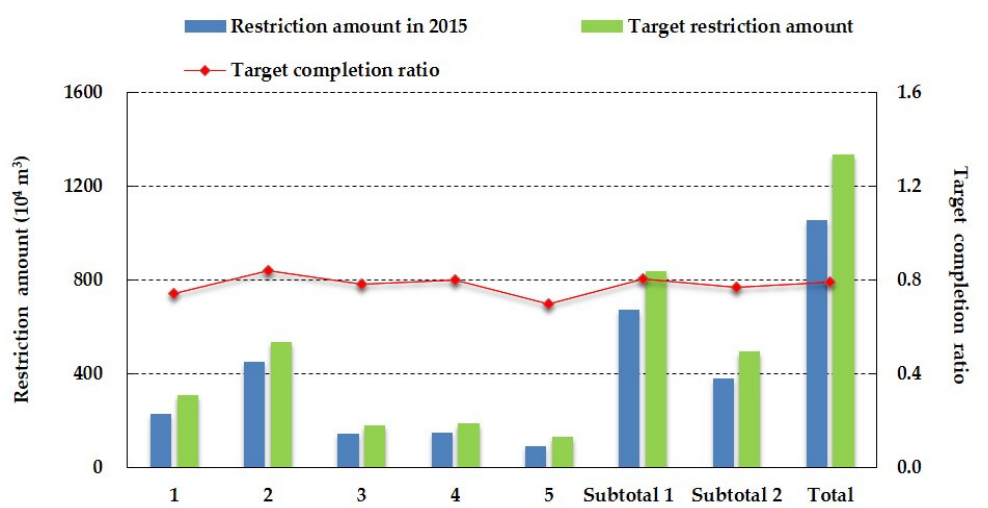

(a)

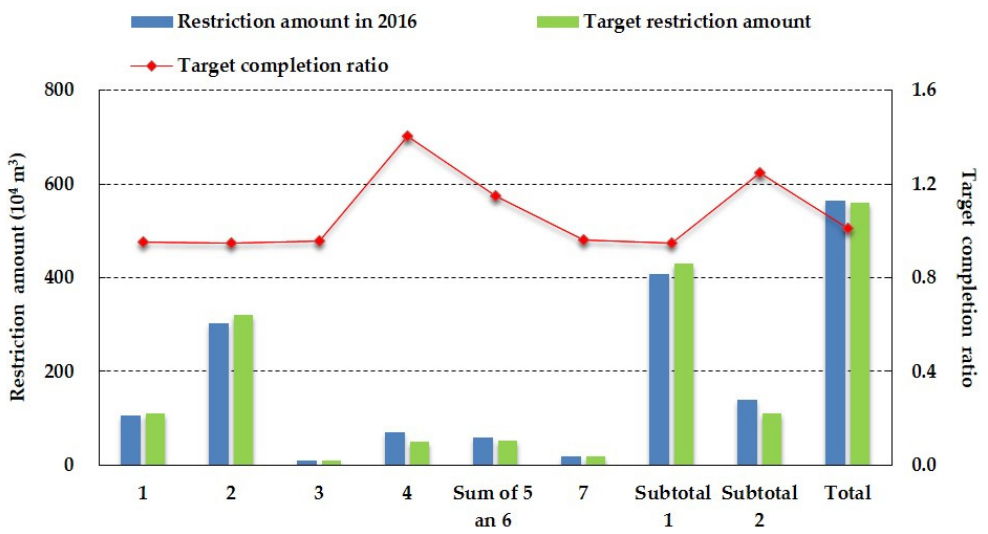

(b)

Figure 6. The restriction amount of agricultural groundwater exploitation in the project regions in 2015 (a) and 2016 (b) of Quzhou County. Restriction amount means the restriction amount of agricultural groundwater exploitation under normal flow conditions in evaluation baseline years (2015/2016); Sum of 5 and 6 mean the total amount of project 5 and project 6; Subtotal 1 represents the total restriction amount of the water conservancy projects; Subtotal 2 means the total restriction amount of the agricultural projects; the project numbers are the same as mentioned above.

Furthermore, in comparison with the target restriction amount of project implementation, we obtained the target completion ratios in 2015 and 2016 (with a total of $79.1 \%$ in 2015 and $100.8 \%$ in 2016) (Figure 6), indicating that the effect in 2016 was better, which may be due to the accumulation of experience in 2014, and the technology of restriction treatments of groundwater exploitation progressing continuously. Although the overall completion ratio was relatively high, the completion ratios of different projects were various. Among them, the completion ratio of project 5 in 2015 was lowest (with only $69.8 \%$ ), which may be caused by the imperfect drip irrigation network system and immature technology of water and fertilizer integration at the beginning of the project (2014), resulting in an unconspicuous restriction effect of partial regions. The restriction effect of project 1 was also 
not excellent, the ratio of which was $74.3 \%$. This may be due to imperfect supporting facilities failing to deliver surface water to the project regions effectively in the first year (2014). However, after the completion of the projects in 2015, the restriction effect of project 1 was improved significantly in 2016, with a completion ratio of $95.4 \%$.

Because the target restriction amount was calculated manually, there may exist human-influenced bias. In order to avoid the error caused by the customization of the target restriction amount and get a better understanding of the restriction effect of each kind of projects, we calculated the restriction amount per square kilometer (Figure 7). The restriction amounts of groundwater exploitation per square kilometer of the total projects in 2015 and 2016 were quite similar, but slightly higher in 2016 (with 134.4 thousand $\mathrm{m}^{3}$ in 2015 and 139.5 thousand $\mathrm{m}^{3}$ in 2016). In addition, the restriction amount per square kilometer of project 5 and project 3 were relatively high in 2015 and 2016, indicating that the two projects have the best effect, and the results are in agreement with Sun et al.'s research [17]. In future, the area of the two kinds of project can be expanded to save more water resources. However, the restriction amount per square kilometer of project 4 were relatively low both in 2015 and 2016, illustrating that the restriction effect of the project was not significant. From the result, the restriction amount per square kilometer of agricultural projects in 2016 was generally higher than that of 2015, and this was effective to prove once again that the restriction effect of agricultural projects in 2016 was very significant. In addition, the restriction effect of the forestry projects was also obvious.

\section{Restriction amount per square kilometer}

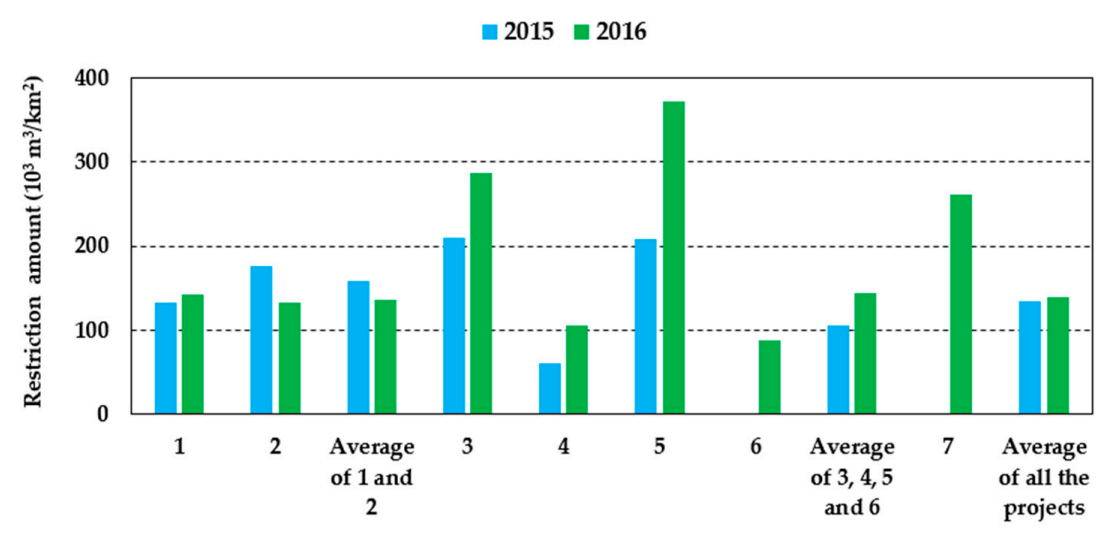

Figure 7. Restriction amount per square kilometer under normal flow conditions in the project regions (thousand $\mathrm{m}^{3}$ ). The project numbers are the same as mentioned above.

\subsection{Effect Verification from Groundwater Depth Variation}

There are many factors that affect the change of groundwater level, such as groundwater pumping, climate change, and land-cover change $[38,39]$. In our study area, groundwater pumping and precipitation variation are the main influences. Therefore, we mainly consider the influence of these two factors. The change of groundwater depth can directly reflect the change of groundwater volume. We have compared the annual average groundwater depth after treatment with the annual average groundwater depth before treatment. In order to eliminate the effect of precipitation change, we choose the similar year of precipitation to compare. The results show that the groundwater depth after treatment has been restored compared with that before treatment, with a rise of $2.8 \mathrm{~m}$ in Disituan Town and $1.6 \mathrm{~m}$ in Houcun Town, respectively (Table 5). At the same time, the continuous variation of the groundwater depth in project regions all showed an ascending trend from 2010 to 2015, with a rising rate of $0.6 \mathrm{~m} /(10$ year) in Disituan Town and $0.5 \mathrm{~m} /(10$ year) in Houcun Town (Figure $8 \mathrm{a})$. It is proved that the groundwater depth has been restored after the implementation of the treatments. However, when the groundwater depths in the project regions present upward trends, the groundwater depths of the wells in the non-project regions, showed decreasing trends, and were accompanied 
by obvious fluctuation (Figure 8b). The groundwater depths of the two wells both have significant downward trends every summer. This may be due to the large area irrigation of crops in early summer. The downward trend was also particularly obvious in 2015, when it was a low flow year. The decline speed was as high as $8 \mathrm{~m}$ from June to July of the observation well in Anzhai Town in 2015. The average annual groundwater depths in 2015 were declined by $1.7 \mathrm{~m}$ in Huaiqiao Township, when compared with 2010 (Table 5). This indicates that the groundwater depths kept decreasing in the areas where no restriction measures were implemented. It is urgent to undertake comprehensive treatment in these areas to restore groundwater depth, otherwise the groundwater will be in danger of exhaustion. In combination with the above results, we can draw a conclusion that the restriction measures have an effective influence on the recovery of the groundwater depths. It is in accordance with the previous conclusions.

Table 5. The groundwater depth variation before and after treatment implemented in project regions and non-project regions $(\mathrm{m})$.

\begin{tabular}{cccccc}
\hline \multirow{2}{*}{ Year } & \multirow{2}{*}{ Precipitation $(\mathbf{m m})$} & \multicolumn{4}{c}{ Annual Average Groundwater Depth (m) } \\
\cline { 3 - 6 } & & Project Region 1 & Project Region 2 & Non-Project Region 1 & Non-Project Region 2 \\
\hline 2010 & 377.8 & 9.8 & 12.8 & 13.0 & 8.7 \\
2015 & 391.1 & 7.0 & 11.2 & 12.3 & 10.4 \\
Variation & & $\uparrow 2.8$ & $\uparrow 1.6$ & $\uparrow 0.7$ & $\downarrow 1.7$ \\
\hline
\end{tabular}

Project Region 1 and Project Region 2 represent the Disituan Town and Houcun Town, respectively; Non-project Region 1 and Non-project Region 2 represent Anzhai Town and Huaiqiao Township, respectively; The groundwater depth is the height of the groundwater surface relative to the sea level, the measurement unit is meter; $\uparrow$ means the groundwater depth has risen, while $\downarrow$ means the groundwater depth has a drawdown.

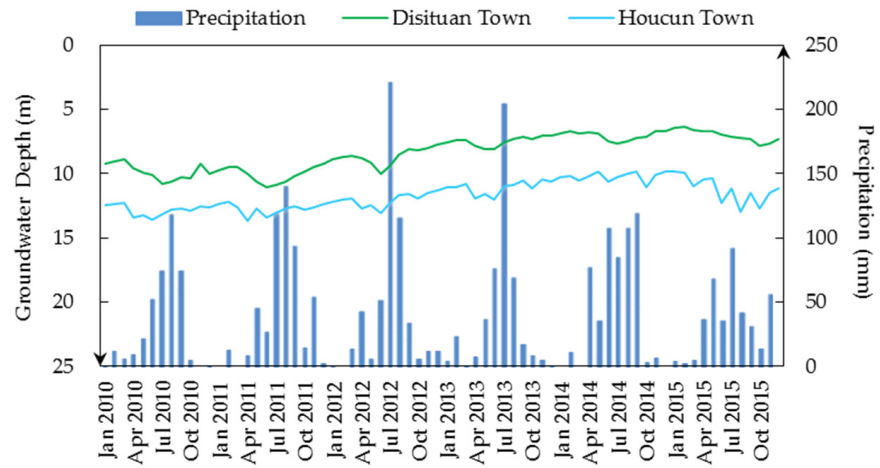

(a)

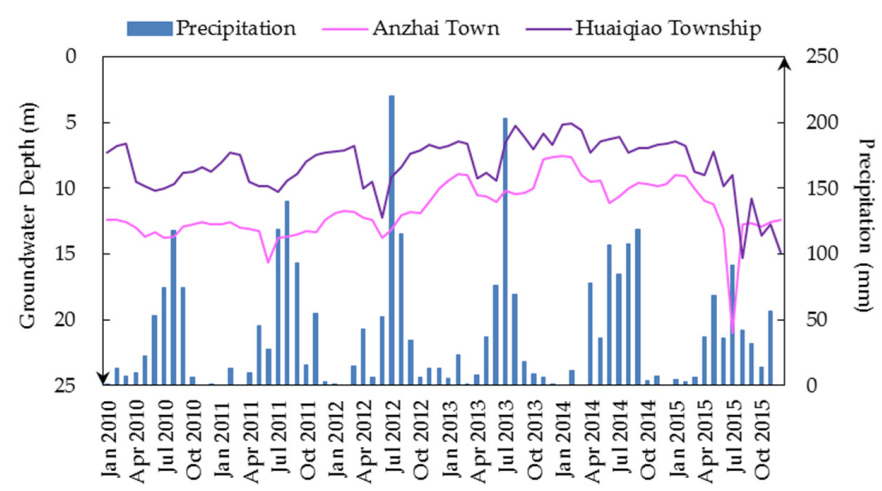

(b)

Figure 8. The variation of groundwater depth in project regions (a) and non-project regions (b) in Quzhou County. 


\section{Conclusions}

The results of field pumping test showed that the water consumption of vegetables was the largest in the test area, followed by wheat. From the view of both the target completion ratio and the restriction amount of groundwater exploitation per square kilometer, the values in 2016 were all higher than in 2015. This demonstrates the restriction effect in 2016 was better. Among different kinds of project, the completion ratios of the water and fertilizer integration of vegetables projects and the surface water substituting groundwater projects in 2015 were not high. However, both of them greatly improved in 2016, indicating that the technology of groundwater restriction is progressing continuously. The water-saving of spring irrigation for winter wheat projects has the highest completion ratio according to the results of 2015 and 2016, but the restriction amount per square kilometer were relatively low. The water and fertilizer integration of vegetables projects have the highest restriction amount per square kilometer, followed by the planting structure adjustment projects. In general, the restriction effect of the agricultural projects was better than that of the water conservancy projects. In addition, the restriction effect of the forestry projects was also obvious. Finally, the variations of groundwater depth demonstrated the restriction measures had an effective influence on the recovery of the groundwater depths. All in all, the comprehensive treatments implemented in 2014 and 2015 in Quzhou County have achieved effective results.

At the same time, the study found that precipitation has been decreasing on the whole since 1956, indicating that the exploitation amount of groundwater is bound to increase in order to ensure grain production. However, although precipitation in 2015 was greatly reduced, the exploitation of groundwater did not increase. Therefore, we conclude that, even if it is a low flow year, the amount of groundwater exploitation can be controlled by the implementation of restriction measures. In addition, based on the analysis of agricultural data, we found that the restriction of groundwater exploitation did not cause the reduction of grain production; on the contrary, there was a slight increasing trend in grain production (with an increasing rate of $5850 \mathrm{~kg} / \mathrm{km}^{2}$ per year from 2013 to 2015). The total planting area of grain in the county was $547.9 \mathrm{~km}^{2}$ in 2013 , and the production was 782.1 thousand $\mathrm{kg}$ per square kilometer. The total planting areas of grain in 2014 and 2015 were 564.0 and $571.7 \mathrm{~km}^{2}$, respectively; and production was 790.8 thousand and 793.8 thousand $\mathrm{kg}$ per square kilometer, respectively. Furthermore, the production of other economic crops has also increased, such as the increasing rates of vegetables and cotton, which were 162.0 thousand and $172.5 \mathrm{~kg} / \mathrm{km}^{2}$ per year, respectively, from 2013 to 2015. The comprehensive treatments in the project regions have not influenced the grain yield. Therefore, comprehensive treatments can also reduce energy consumption and reduce carbon emissions, which is of great significance for the green and sustainable development of the region and the global world.

Although the restriction effect is significant, there are still many aspects that need to be further improved. In future, a comparison can be made with the research results of the water balance method. In addition, the exploitation of groundwater is mainly dependent on fossil-fuel generated electricity in the county, which may produce large amounts of carbon emissions, and solar or wind power generation can be developed in the future.

Author Contributions: B.W. designed the experiments and provided overall guidance; T.X. drafted the manuscript; B.W., D.Y., T.X., W.B., P.D., F.L., Y.W. and J.M. finalized the manuscript. All authors reviewed the manuscript.

Funding: This work was supported by the National Key Research and Development Project (No. 2016YFA0601503), and the Chinese National Natural Science Foundation (No. 91547209 and No. 41571037).

Acknowledgments: We are grateful to the relevant departments of Hebei Province, Handan city and Quzhou County for sharing the data needed in this study. We also want to express our gratitude to Wang Jianhua, Zhao Yong, Tang Kewang, Liu Jiahong, Lu Chuiyu, Shao Weiwei and Cao Guoliang for providing us with guidance in research methods and giving suggestions on the research conclusions. We also thank the editors and anonymous reviewers.

Conflicts of Interest: The authors declare no conflict of interest in any aspect of the data collection, analysis or the preparation of this paper. 


\section{References}

1. Wu, X.; Zhao, W.; Li, J. Division and countermeasures of shallow groundwater overexploitation region in plain area of Handan City. Groundwater 2012, 34, 54-56. (In Chinese)

2. Jin, J.J.; Pan, M. Present Situation of ground subsidence disaster and countermeasures for disaster prevention and reduction in China. J. Catastrophol. 2007, 22, 117-120. (In Chinese)

3. Deb Roy, A.; Shah, T. Socio-Ecology of Groundwater Irrigation in India; IWMI Working Papers; IWMI-TATA Water Policy Research Program: Gujarat, India, 2003.

4. Moore, N.; Rojstaczer, S. Irrigation's influence on precipitation: Texas High Plains, USA. Geophys. Res. Lett. 2002, 29, 2-1-2-4. [CrossRef]

5. Chen, X.; Hu, Q. Groundwater influences on soil moisture and surface evaporation. J. Hydrol. 2004, 297, 285-300. [CrossRef]

6. Yuan, X.; Xie, Z.; Zheng, J.; Tian, X.; Yang, Z. Effects of water table dynamics on regional climate: A case study over East Asian monsoon area. J. Geophys. Res. 2008, 113. [CrossRef]

7. Kustu, M.D.; Fan, Y.; Robock, A. Large-scale water cycle perturbation due to irrigation pumping in the US High Plains: A synthesis of observed streamflow changes. J. Hydrol. 2010, 390, 222-244. [CrossRef]

8. Kirby, M.; Ahmad, M.U.D.; Mainuddin, M.; Khaliq, T.; Cheema, M.J.M. Agricultural production, water use and food availability in Pakistan: Historical trends, and projections to 2050. Agric. Water Manag. 2016, 179, 34-46. [CrossRef]

9. Famiglietti, J.S. The global groundwater crisis. Nat. Clim. Chang. 2014, 4, 945-948. [CrossRef]

10. Wada, Y.; Beek, L.P.H.V.; Bierkens, M.F.P. Nonsustainable groundwater sustaining irrigation: A global assessment. Water Resour. Res. 2012, 48, 335-344. [CrossRef]

11. Wada, Y.; Wisser, D.; Bierkens, M.F.P. Global modeling of withdrawal, allocation and consumptive use of surface water and groundwater resources. Earth Syst. Dyn. 2014, 4, 355-392. [CrossRef]

12. Rodell, M.; Velicogna, I.; Famiglietti, J.S. Satellite-based estimates of groundwater depletion in India. Nature 2009, 460, 999-1002. [CrossRef] [PubMed]

13. Scanlon, B.R.; Mcmahon, P.B. Groundwater depletion and sustainability of irrigation in the US High Plains and Central Valley. Proc. Natl. Acad. Sci. USA 2012, 109, 9320-9325. [CrossRef] [PubMed]

14. Yang, Y.H.; Watanabe, M.; Zhang, X.Y.; Zhang, J.Q.; Wang, Q.X.; Hayashi, S. Optimizing irrigation management for wheat to reduce groundwater depletion in the piedmont region of the Taihang Mountains in the North China Plain. Agric. Water Manag. 2006, 82, 25-44. [CrossRef]

15. Karimi, P.; Qureshi, A.S.; Bahramloo, R.; Molden, D. Reducing carbon emissions through improved irrigation and groundwater management: A case study from Iran. Agric. Water Manag. 2012, 108, 52-60. [CrossRef]

16. Obama, B. The irreversible momentum of clean energy. Science 2017, 355, aam6284. [CrossRef] [PubMed]

17. Sun, H.Y.; Liu, X.J.; Shao, L.W.; Chen, S.Y.; Liu, X.W.; Zhang, X.Y. Effects of different cropping pattern on ground water balance and economic water use efficiency in the Hebei Low Plain. Chin. Agric. Sci. Bull. 2014, 30, 214-220. (In Chinese)

18. Liu, C.M.; Yu, J.J.; Kendy, E. Groundwater exploitation and its impact on the environment in the North China Plain. Water Int. 2001, 26, 265-272.

19. Li, F.J.; Yang, J.X.; Zhang, X.L. Discussion on the development of groundwater resources in Hebei and the disaster caused by it. Groundwater 2011, 33, 36-38. (In Chinese)

20. Shi, J.S.; Wang, Z.; Zhang, Z.J.; Fei, Y.; Li, Y.; Zhang, F.; Chen, J.; Qian, Y. Assessment of over-exploitation of deep groundwater in the North China Plain. Geosci. Front. 2011, 2, 593-598. [CrossRef]

21. Bouwer, H. Land subsidence and cracking due to ground-water depletion. Groundwater 1977, 15, 358-364. [CrossRef]

22. Konikow, L.F.; Kendy, E. Groundwater depletion: A global problem. Hydrogeol. J. 2005, 13, 317-320. [CrossRef]

23. Hu, Z.R.; Cao, W.J.; Ren, Q.C.; Yang, B.Q.; Du, C.Y.; Jin, L. Study on groundwater over-exploitation and its environmental impact. Water Resour. Prot. 1995, 2, 37-41.

24. Wolff, R.G. Relationship between horizontal strain near a well and reverse water level fluctuation. Water Resour. Res. 1970, 6, 1721-1728. [CrossRef]

25. Rothenburg, L.; Obah, A.; El, B.S. Horizontal ground movements due to water abstract and formation earth fissures. Int. J. Rock Mech. Min. Sci. Geomech. Abstr. 1996, 1996, 343A-344A. 
26. Holzer, T.L. Ground failure induced by groundwater withdrawal from unconsolidated sediments. Rev. Eng. Geol. 1984, 6, 67-105.

27. Boling, J.K. Earth-fissure movements in south-central Arizona, USA. In Proceedings of the 3rd International Symposium on Land Subsidence, Venice, Italy, 19-25 March 1984; pp. 757-766.

28. Lee, J.Y.; Yi, M.J.; Song, S.H.; Lee, G.S. Evaluation of seawater intrusion on the groundwater data obtained from the monitoring network in Korea. Water Int. 2008, 33, 127-146. [CrossRef]

29. Karatzas, G.P.; Dokou, Z. Optimal management of saltwater intrusion in the coastal aquifer of Malia, Crete (Greece), using particle swarm optimization. Hydrogeol. J. 2015, 23, 1181-1194. [CrossRef]

30. Zou, J.; Xie, Z.H.; Yu, Y.; Zhan, C.S.; Sun, Q. Climatic responses to anthropogenic groundwater exploitation: A case study of the Haihe River Basin, Northern China. Clim. Dyn. 2014, 42, 2125-2145. [CrossRef]

31. Yuan, Z.J.; Xu, Y.Z.; Xie, L.Y. Correlation among farmland water consumption, grain yield and groundwater dynamics in the Hebei Plain. Chin. J. Eco-Agric. 2014, 22, 904-910. (In Chinese)

32. Dalin, C.; Wada, Y.; Kastner, T.; Puma, M.J. Groundwater depletion embedded in international food trade. Nature 2017, 543, 700-704. [CrossRef] [PubMed]

33. Chen, Y.Y.; Wang, W.; Xu, L.M. Analysis and exploration of the implementation of the management measures for the comprehensive treatment of groundwater overexploitation in Hebei. Hebei Water Resour. 2015, 2015, 31-32. (In Chinese)

34. Li, C.Y.; Wang, H.F.; Bian, L.J. The effect of ecological water network construction on groundwater environment in Handan. Groundwater 2016, 38, 73-76. (In Chinese)

35. Hu, X.S. Water supplement of shallow groundwater by water network construction in Handan plain area. Water Sci. Eng. Technol. 2015, 2015, 33-36. (In Chinese)

36. Wang, S.L.; Wang, X.J.; Jiang, Z. Research on water conservancy project measures for over-exploitation groundwater control and management. China Rural Water Hydropower 2016, 2016, 8-10. (In Chinese)

37. Liu, D.L. Hebei Province, " $1+5$ " Groundwater overdraft comprehensive management model. Rev. Econ. Res. 2015, 51, 24-27. (In Chinese)

38. Yihdego, Y.; Danis, C.; Paffard, A. Groundwater engineering in an environmentally sensitive urban area: Assessment, landuse change/infrastructure impacts and mitigation measures. Hydrology 2017, 4, 37. [CrossRef]

39. Yihdego, Y.; Webb, J.A. Modeling of bore hydrographs to determine the impact of climate and land-use change in a temperate subhumid region of southeastern Australia. Hydrogeol. J. 2011, 19, 877-887. [CrossRef] 